\title{
OPEN
}

Published online: 31 January 2020

\section{Author Correction: Transcriptome and digital gene expression analysis unravels the novel mechanism of early flowering in Angelica sinensis}

GuangYu 1 , Yuan Zhou, Juanjuan Yu, Xueqin Hu, Ye Tang, Hui Yan \& Jinao Duan

Correction to: Scientific Reports https://doi.org/10.1038/s41598-019-46414-2, published online 11 July 2019

In the original version of this Article, Guang Yu and Yuan Zhou were omitted as equally contributing authors. This has now been corrected in the PDF and HTML versions of the paper.

(c) (i) Open Access This article is licensed under a Creative Commons Attribution 4.0 International License, which permits use, sharing, adaptation, distribution and reproduction in any medium or format, as long as you give appropriate credit to the original author(s) and the source, provide a link to the Creative Commons license, and indicate if changes were made. The images or other third party material in this article are included in the article's Creative Commons license, unless indicated otherwise in a credit line to the material. If material is not included in the article's Creative Commons license and your intended use is not permitted by statutory regulation or exceeds the permitted use, you will need to obtain permission directly from the copyright holder. To view a copy of this license, visit http://creativecommons.org/licenses/by/4.0/.

(c) The Author(s) 2020 